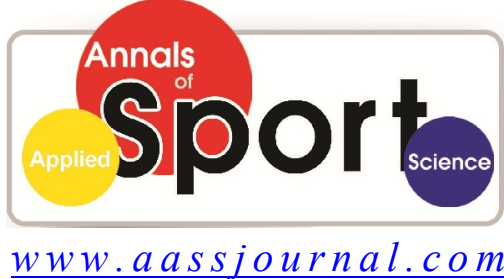

ISSN (Online): $2322-4479$

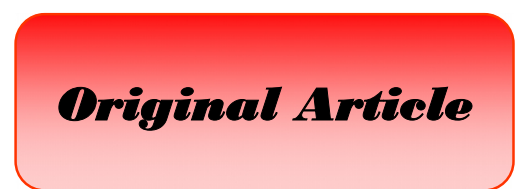

Received: $26 / 02 / 2014$

Accepted: 30/04/2014

\title{
Effects of 8 Weeks Aerobic Training on the Social-Physical Anxiety in Women with Multiple Sclerosis
}

\author{
Forough Rahmati*, Ehsan Zareian
}

- Department of Motor Behavior, Faculty of physical education and sport sciences, Allameh Tabataba'i University, Tehran, Iran.

\begin{abstract}
Nowadays, ailments which are known as specific diseases make the society we live in suffer, and scientific researches pay much attention to the effect of sport and physical activity on these diseases and introduce sports as treatment for them. The purpose of this study was to check the effect of an aerobic training course on social-physical anxiety in women with Multiple Sclerosis (MS). The study population consisted of all inactive women reported by MS community of Tehran in 2012. Of them, 24 ones have been chosen at random (age 32 \pm 11 years old) and selected in two groups of control and experimental at random. The social-physical anxiety scale (SPAS) was used to measure the social-physical anxiety in these patients. The findings indicated a noticeable decrease in the amount of social-physical anxiety in women with MS after 8 weeks of aerobic training $(\mathrm{P}<0.001)$. Eventually, we can conclude that aerobic training are effective on decreasing the socialphysical anxiety of patients suffering from MS, and it can, by its nature, decrease the social-physical anxiety in these people and promote health and participation in sports activities.
\end{abstract}

Key Words: Aerobic, Anxiety, Social-Physical Anxiety, Multiple Sclerosis, MS.

Corresponding Author:

Forough Rahmati

E-mail: forough_rahmati2012@yahoo.com 


\section{INTRODUCTION}

People with specific diseases have formed an important part of our society nowadays. These people need a lot of nonmedical treatments as well as medical treatments to decrease a part of difficulties relating to their disease. Today, sport and physical activity have been known as one of the most efficient nonmedical treatments all over the world. The extent of participation in sports activities have been reported very low in people with specific diseases, especially if these diseases influence the physical appearance and figure of patients (1). These people avoid showing up in sports environments and doing physical activities because of their weak body image, and in fact, the negative body image is an obstacle for these people to participate in sports and physical activities because of considering the sports environments as threat and possibility of being humiliated (2). The body image is a mental picture which each individual has about his/her body. This mental picture has two dimensions of cognitive-descriptive and evaluative-emotional. The cognitivedescriptive dimension means how an individual understands his/her physical features, and the evaluative-emotional dimension means the extent of an individual's satisfaction with himself/herself in terms of perceived characteristics (3). These people also have more social-physical anxiety than other members of society (4).

Social, physical anxiety is one of the problems associated with dissatisfaction with body condition, and it occurs when the individual feels that his/her physical characteristics is the potential reason for being laughed at or humiliated (5). People with this anxiety develop a certain and constant fear of being ashamed of or negatively evaluated in social situations at the time of performing activities in the presence of others (6). These people are more likely to present themselves in a way that they are not so different from others, generally bearing more stress while encountering other people (5). The outward figure of body as one of the unavoidable elements in most social interactions is considered to be an important field of selfpresentation. In every social encounter, mutual evaluation of each other's figure and appearance by people is probable. The discomfort experienced by the outward figure of body in such situations is called social-physical anxiety. To say more accurately, the anxiety caused by the individual's doubt in his/her ability to make the favorable impression or avoid the unfavorable impression on others through his/her body figure and shape is called the social-physical anxiety (7). The conducted researches report the social-physical anxiety in women to be far more than in men (8). There is no consistency regarding sports and physical activities with social-physical anxiety of researches (9). Some of the researches consider this factor as a reason for participation in sport, while some others introduced it as an obstacle for participation in physical activities because of sports environment's being considered as a threat and possibility of being humiliated (10). Researches also indicated that socialphysical anxiety in people with multiple sclerosis or MS is far higher than in normal people (11).

A chronic disease of the nervous system, MS acts to destroy the myelin of central nervous system progressively and in an autoimmune way (12). The destruction of myelin often in specific regions like optic nerve, brain stem, cerebellum, and the white matter of brain hemispheres results in emergence of a set of symptoms such as sensory loss, weakness, muscle cramps, visual disturbances, cognitive dysfunction, trembling of limbs, abnormal walking, balance loss, and so on. These symptoms are unpredictable from one person to another 
and in terms of the duration of illness which is very debilitating (13). Almost 350000 people are suffering from this disease in the US (14). This number has been reported to be between 50000 and 60000 in Iran, and its most common age period is between 20 and 35 with an extent of spread in women as twice as men (15). Symptoms like lack of balance, myasthenia, spasm, fatigue, paresis, and abnormal walking are all included in factors which have caused to decrease mobility in these patients and resulted in negative effects on daily activities, quality of life, self-image, and social-physical anxiety (16-18). People with MS avoid sports and physical activities because of motor disabilities. Sport has been reported to be one of the effective ways of controlling this disease. Nowadays, sports and physical activities are advised as helpful treatments for most of specific diseases and mostly known as a nonmedical treatment. The effect of sport with the necessity and continuity of its presence in the life of people with MS is a matter well-studied in most countries nowadays (19). Many researches indicated that fatigue, pain, depression, and absence in sports activities have negative effects on the intensity of disease and factors involved in patients' daily lives $(15,17,20)$. During the previous years, special attention has been paid to sport and aerobic ability especially aerobic sports.

Aerobic exercise is one of the aerobic methods which creates much joy and happiness and is safe and inexpensive as well, being performable even in the life environment and without requiring any special tools (21). These exercises include chained movements of 32 times, consisted of movements of 4 or 8 times, and they are required to be performed to music. These exercises reduce tactile disorders, fatigue, spastic disorders, coordination difficulties, disease progression, increase in muscular strength, and balance in these patients (22). van den Berg et al. (2006) recommends these activities as efficient and helpful by conducting a research on the effect of aerobic activities on reducing MS symptoms (23). Aerobic trainings, if especially in done in hot water, are quite helpful in reducing fatigue and motor disabilities of patients (24, 25). Rietberg Marc et al. (2004), in a review paper, studied the effect of exercise treatment in these patients and introduced the exercise as a miracle to cure motor disabilities and to control the disease progression (26).

Although sport cannot directly stop the process of myelin destruction or reconstruct it, it supports the individual with MS in other ways (19). Many researches have been reported on the positive effect of sport and exercise treatment in patients with MS; they indicate that these activities have had positive outcomes in terms of social relationships, mental issues, and motor disabilities in these patients, controlling and reducing the progression of disease (21). Nonetheless, some researches have reported the otherwise (16).

According to the above-mentioned material, the benefits of exercise and physical activity in MS patients have been discussed in many researches; however, the existing problem regards the mental reasons for the absence of these patients in physical activities. Why patients with specific diseases like MS which affects the individual's appearance are less likely to participate in sports communities has been paid much less attention. In the present research, the researcher tries to increase the extent of sports participation of patients in future through the experience of a joyful physical activity by decreasing socialphysical anxiety in patients with MS, considering it to be one of the major reasons for them to be absent in such activities. For, sport is considered to be one of the major non-medical treatments for these patients nowadays. Thus, this paper aims for the 
question, "Do aerobic trainings affect the social-physical anxiety in women with MS?"

\section{MATERIALS AND METHODS}

This research is of applied quasiempirical type with pretest-posttest plan including the control group.

Participants. The statistical population consisted of all the female patients with MS from Tehran's MS association. They were the ones who avoided participating in sports activities, according to studies, reviewing patient records, and intelligence by social workers and doctors. Out of 68 inactive reported women, 24 ones were chosen at random (age $32 \pm 11$ years old) and put into two groups of control and experimental. The statistical samples of this research had the disability progression scale of less than or equal to 4.5 , and they could stand and walk without aiding devices.

Instruments. To evaluate the extent of social-physical anxiety in the present paper, the social-physical anxiety scale [SPAS by Motl and Conroy, 2000 (5)] which is a selfreporting scale consisting of 7 Likert items and is based on 12-item scale of Hart, Leary, and Rejeski (1989) has been used. This scale measures the extent of anxiety experienced by a person on his/her body figure in a social situation. The subjects specified their answers to each item on Likert's scale from 1 (not at all) to 5 (very much) suiting their statuses. The score of subjects ranged from 7 to 49. The higher the test's score is, the higher the social-physical anxiety is in the individual. The time reliability of this test has been reported to be 0.94 , according to the retesting method (27). Yousefi, Hassani, and Shokri (2009) have reported the elemental reliability and validity of this scale in Iranian student population (28). According to the results of this elemental analysis which was done on the data acquired by studying 237 students of university of Kermanshah (108 girls and 129 boys), the elemental structure of this scale is well-depicted in both genders (29). Calculating Cronbach's Alpha for all items indicated that the internal stability of the test was 0.85 for female students and 0.81 for male ones, a stability which is considered acceptable (28).

Research Process. After placing the people in two groups of control and experimental, a pre-test was given to the subjects through answering the socialphysical anxiety questionnaire. After that, the control group was under aerobic trainings for 8 weeks. The aerobic trainings which were designed by consulting some experienced coaches of this field and patients' physician were given to patients three 40-minute sessions per week for 8 weeks. Each session included 10 minutes of warming-up, 20 minutes of performing the main moves, and 10 minutes of relaxation and cooling. It should be noted that move chains included 8 very simple and clear so that the subjects could perform them easily. The music was designed in a slow a beatper-minute rhythm, so the patients could perform the exercises with a low heart rate and controlled intensity. Also, patients' body temperature increase due to doing exercises was being strictly controlled, because these people showed extreme sensitiveness to heat and got hysteric in acute conditions due to the damage to the myelin sheath. It should be noted that there was no compulsion to continue the exercise during the sessions, and the subject would be prohibited from continuing the exercise if any tiredness or unpleasant feeling were observed. In fact, the purpose of doing these exercises was to gain team sport experience and to put people together with their other teammates. The control group was asked not to participate in any organized and regular exercise program. After finishing the exercises, a post-test was given to both groups again in order to 
evaluate the differences between groups and assess the effect of interventions.

Statistical Analysis. After collecting data regarding social-physical anxiety, descriptive statistics including frequency distribution, central indexes, and dispersion were used. Also, inferential descriptive including Kolmogrov-Smirnov test (to determine the normal distribution of data) and ANCOVA (to determine the difference between means) were used at the significance level of $\mathrm{p} \leq 0.05$. The dependent $\mathrm{t}$ test with modified freedom degrees in
Bonferroni method was used to specify the position of difference. The applications SPSS and EXCEL were used to analyze the data.

\section{RESULTS}

The results indicated a significant difference between experimental group $(\mathrm{M} \pm \mathrm{SD}=)$ and control group $(\mathrm{F}=127.53$; $\mathrm{P}=0.001 ; \eta 2=0.85)$, meaning that aerobic trainings decreased the physical anxiety of experimental group by impact coefficient of 0.85 based on mean (Table 1, Figure 1).

Table 1. Descriptive statistics of social-physical anxiety in two groups of experimental and control

\begin{tabular}{|c|c|c|c|c|c|}
\hline \multirow[b]{2}{*}{ Group } & \multicolumn{2}{|c|}{ Mean \pm Standard Deviation } & \multicolumn{3}{|c|}{ ANOCOVA statistics } \\
\hline & Pretest & Posttest & $\mathrm{F}$ & $\mathrm{P}$ & $\eta^{2}$ \\
\hline Experimental & $41.08 \pm 4.6$ & $14 \pm 5.7$ & \multirow{2}{*}{127.53} & \multirow{2}{*}{$0.001^{*}$} & \multirow{2}{*}{0.85} \\
\hline Control & $39.83 \pm 7.08$ & $39.50 \pm 7.07$ & & & \\
\hline
\end{tabular}

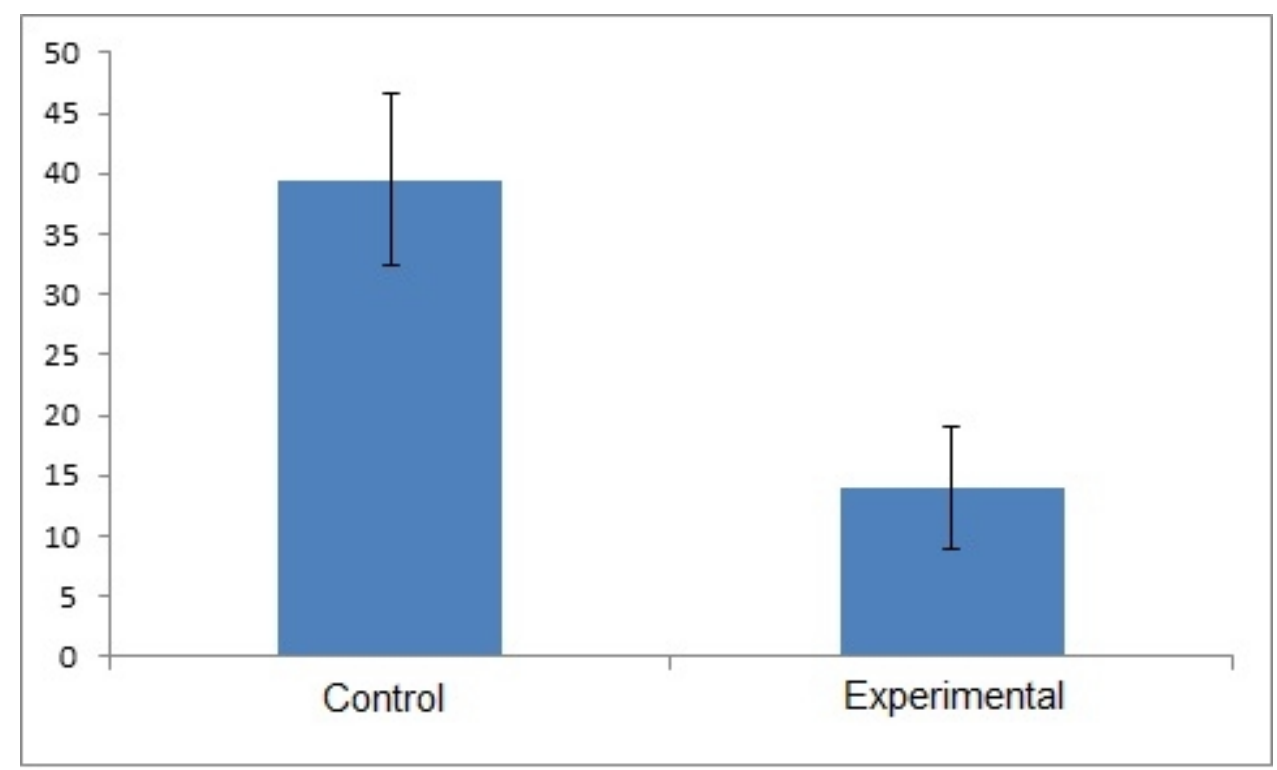

Figure 1. Difference between social-physical anxiety of experimental group and control group

\section{DISCUSSION and CONCLUSION}

The purpose of the present paper was to study the effects of one course of aerobic trainings on the extent of social-physical anxiety in women with MS. According to the findings of research, a significant difference was observed in the extent of social-physical anxiety before and after training interventions. In fact, doing aerobic trainings could decrease social-physical anxiety in these patients and prepare the ground for sports and physical activities to be continued by these people. Of benefits gained by sports and physical activities, 
development of the neural mechanisms in these patients could be pointed out. Since the destruction of neural mechanisms is one of the main reasons of this disease and is actually responsible for reducing the strength and movability in these patients, it could be useful and efficient (30). Also, the benefits of aerobic trainings and team sports to reduce the mental and disorder symptoms have been mentioned in many researches whose results are consistent with the present one (31). In fact and among different types of sports, aerobic trainings which hugely consume oxygen cause important metabolic changes including metabolism improvement, decreased levels of epinephrine and norepinephrine, decreased level of cholesterols and triglycerides, strengthening the immune system, improvement of endorphin secretions, and improvement of mental or mood status. The main point is that the demyelination process doesn't stop during these activities, but it becomes slower. The period of oxidation reduces when muscular-skeletal system is not activate, a fact which is an important factor in emerging mental and mood disorders and making daily activities of life lag (32). The capacity of oxidation in muscles increases by doing sports exercises; therefore, the aerobic biochemical system gets stimulated to cause adaptability and increases the extent of inhaled oxygen in body. Some diseases like MS stops the flow of oxygen in each of the above-mentioned phases and reduces the functional capacity, but aerobic trainings like aerobics can create physiological adaptability in the functionality of aerobic energy system, increase individual's ability to function, and even improve the functionality capacity in terms of disease progression; as a result, disease symptoms like fatigue and inability to move extremities will get slow to some extent, a fact which may improve patient's mental status. Other benefits of regular aerobic trainings for these patients include increase in power, improvement of body status, decrease in fatigue, improvement of mood, increase in self-confidence, and general feeling of wellbeing (33). For example, the effect of aerobic trainings on mental components of MS patients has been studied; as a result, these exercises have been evaluated positive (34). In another research in which the effects of yoga exercises on physical fitness components of these people were studied, a good development was reported after on course of training (35). However, studies show that people with specific diseases like MS avoid participating in sports and group exercises (36). There are researches which consider sports and physical activities harmful for these people $(16,21)$ and prevent them from doing sports exercises. These results can be explained by the degree and progress rate of the disease, because MS patients can do sport exercises and make the disease develop more slowly if the disease is mild (29). It should be noted that the type of sports activity is very important, too, because that heavy exercises have not been advised for these patients at all (12). Finally, the results of inconsistent researches, in comparison with the result of present research, can be explained through the different types of physical applied in them and disease degree of severity. Eventually and considering the notable effect of sport and physical activities on controlling specific diseases, studying why patients with MS or other specific disease or other patients whose appearances are damaged due to illness avoid sports is highly considerable. Given the conducted studies, the fear of participating in sports communities is one of the main reasons of this problem because of considering them as threats and being laughed at by other members of society. One of the major reasons of this avoidance is social-physical anxiety in these patients which have been reported very high (37). Consequently, these people can be prepared to take part in sports activities and make 
them aware of sports' benefits in controlling the disease by reducing the social-physical anxiety. To explain the efficiency of aerobic trainings in reducing social-physical anxiety of MS patients, two possibilities should be taken into account: first, participating in one course of training which is done in a group brings patients the experience and joy of an energetic activity which encourage them to feel it again and not to be anxious like before, as a result. Second, participating in a sports environment and doing physical activities increase the self-image and self- confidence connected with increment in physical fitness or reduction in disease symptoms, especially motor debilitating symptoms in these patients, therefore, decrease social-physical anxiety and have a positive mental effect on them, encouraging them to continue this progress consistently. At last, studying the other effective components on the absence of patients in sports activities seems very helpful. We hope to propose approaches to fix a few problems of people with specific diseases by doing such researches.

\section{REFFRENCES}

1. Fallon AE, Rozin P. Sex differences in perceptions of desirable body shape. Journal of abnormal psychology. 1985;94(1):102-5.

2. Yousefi B, Tadibi V, Hasani Z. The Effect of Gender and Sport on Satisfaction from Body Areas and Social Physique Anxiety in Islamic Azad University Students. Journal of Sport Management. 2010;2(6):121-256.

3. Cash TF, Pruzinsky T. Body Image: A Handbook of Theory, Research, and Clinical Practice. New York: Guilford Press; 2004. 530 p.

4. Haase AM, Prapavessis H, Glynn Owens R. Perfectionism, social physique anxiety and disordered eating: a comparison of male and female elite athletes. Psychology of Sport and Exercise. 2002;3(3):209-22.

5. Motl RW, Conroy DE. Validity and factorial invariance of the Social Physique Anxiety Scale. Medicine and science in sports and exercise. 2000;32(5):1007-17.

6. Melyani M, Shairi MR, Ghaedi G, Bakhtirari M, Tavali A. The Effectiveness of Cognitive-Behavioral Group Therapy Based on Heimberg`s Model on the Decrease of Social Anxiety Symptoms. Iranian Journal of Psychiatry and Clinical Psychology. 2009;15(1):42-9 [Article in Farsi].

7. Davison T, McCabe M. Relationships Between Men's and Women's Body Image and Their Psychological, Social, and Sexual Functioning. Sex Roles. 2005;52(7-8):463-75.

8. Lindwall M, Lindgren E-C. The effects of a 6-month exercise intervention programme on physical selfperceptions and social physique anxiety in non-physically active adolescent Swedish girls. Psychology of Sport and Exercise. 2005;6(6):643-58.

9. Field AE, Austin SB, Camargo CAJ, Taylor CB, Striegel-Moore RH, Loud KJ, et al. Exposure to the mass media, body shape concerns, and use of supplements to improve weight and shape among male and female adolescents. Pediatrics. 2005;116(2):e214-e20.

10. Jackson T, Hong C. Sociocultural Influences on Body Image Concerns of Young Chinese Males. Journal of Adolescent Research. 2008;23(2):154-71.

11. Maghzi AH, Etemadifar M, Saadatnia M. Clinical and demographical characteristics of primary progressive multiple sclerosis in Isfahan, Iran. European Journal of Neurology. 2007;14(4):403-7.

12. Brunner LS, Smeltzer SCOC, Bare BG, Hinkle JL, Cheever KH. Brunner \& Suddarth's Textbook of Medicalsurgical Nursing: Wolters Kluwer Health/Lippincott Williams \& Wilkins; 2010. 2240 p.

13. Dennison L, Moss-Morris R, Chalder T. A review of psychological correlates of adjustment in patients with multiple sclerosis. Clinical Psychology Review. 2009;29(2):141-53.

14. MSAA. MS Overview (What is Multiple Sclerosis?). Multiple Sclerosis Association of America; 2011 [Aug 7 2014]; Available from: http://www.mymsaa.org/about-ms/overview/.

15. Soltanzadeh A. Neurologic disorders. 1st ed. Tehran: Jafari Press; 2006. 406 p.

16. Crayton HJ, Rossman HS. Managing the symptoms of multiple sclerosis: A multimodal approach. Clinical Therapeutics. 2006;28(4):445-60.

17. Romberg A, Virtanen A, Ruutiainen J, Aunola S, Karppi SL, Vaara M, et al. Effects of a 6-month exercise program on patients with multiple sclerosis A randomized study. Neurology. 2004;63(11):2034-8.

18. Shah A. Fatigue in Multiple Sclerosis. Physical Medicine and Rehabilitation Clinics of North America. 2009;20(2):363-72.

Rahmati, F., and Zareian, E. (2014). Ann Appl Sport Sci, 2(2): 65-74. 
19. Mostert S, Kesselring J. Effects of a short-term exercise training program on aerobic fitness, fatigue, health perception and activity level of subjects with multiple sclerosis. Multiple Sclerosis. 2002;8(2):161-8.

20. Ng AV, Miller RG, Gelinas D, Kent-Braun JA. Functional relationships of central and peripheral muscle alterations in multiple sclerosis. Muscle \& nerve. 2004;29(6):843-52.

21. Tadibi V, Bayat Z. Effect of eight weeks aerobic training and drug intervention on quality of life in women with type 2 diabetes. Journal of Gorgan University of Medical Sciences. 2012;14(2):30-6 [Article in Farsi].

22. White LJ, McCoy SC, Castellano V, Gutierrez G, Stevens JE, Walter GA, et al. Resistance training improves strength and functional capacity in persons with multiple sclerosis. Multiple Sclerosis. 2004;10(6):668-74.

23. van den Berg M, Dawes H, Wade DT, Newman M, Burridge J, Izadi H, et al. Treadmill training for individuals with multiple sclerosis: a pilot randomised trial. Journal of Neurology, Neurosurgery \& Psychiatry. 2006;77(4):531-3.

24. Hejazi M, Soltani M, Nornematolahi S, Ashkanifar M. The Effect of Aquatic Aerobic Training on Fatigue Severity in Multiple Sclerosis Patients. Iranian Journal of Health and Physical activity. 2012;3(1):42-8.

25. Kileff J, Ashburn A. A pilot study of the effect of aerobic exercise on people with moderate disability multiple sclerosis. Clinical Rehabilitation. 2005;19(2):165-9.

26. Rietberg Marc B, Brooks D, Uitdehaag Bernard MJ, Kwakkel G. Exercise therapy for multiple sclerosis. Cochrane Database of Systematic Reviews [Internet]. 2004; (3). Available from: http://onlinelibrary.wiley.com/doi/10.1002/14651858.CD003980.pub2/abstract.

27. Scott LA, Burke KL, Joyner AB, Brand JS. Examining the Stability of the 7-Item Social Physique Anxiety Scale Using a Test-Retest Method. Measurement in Physical Education and Exercise Science. 2004;8(2):57-62.

28. Yousefi B, Hassani Z, Shokri O. Reliability and Factor Validity of the 7-Item Social Physique Anxiety Scale (SPAS-7) among University Students in Iran. World Journal of Sport Sciences. 2009;2(3):201-4.

29. Salehi J, Rahmani A. The Role of Social Physique Anxiety in Determining the Motivation for Participating in Physical Activity. Journal of Motor Learning and Movement. 2010;2(6):81-101 [Article in Farsi].

30. Dalgas U, Stenager E, Ingemann-Hansen T. Multiple sclerosis and physical exercise: recommendations for the application of resistance-, endurance- and combined training. Multiple Sclerosis. 2007.

31. Patti FMD, Ciancio MMD, Cacopardo MMD, Reggio EMD, Fiorilla TMD, Palermo FP, et al. Effects of a short outpatient rehabilitation treatment on disability of multiple sclerosis patients. J Neurol. 2003;250(7):861-6.

32. Sabapathy NM, Minahan CL, Turner GT, Broadley SA. Comparing endurance- and resistance-exercise training in people with multiple sclerosis: a randomized pilot study. Clinical Rehabilitation. 2011;25(1):14-24.

33. Pazokian M, Shaban M, Zakerimoghdam M, Mehran A, Sanglaje B. Effect of Aerobic Exercises on the Level of Fatigue in Patients with Multiple Sclerosis. Journal of Nursing Education (JNE). 2013;2(2):64-73 [Article in Farsi].

34. Brown TR, Kraft GH. Exercise and rehabilitation for individuals with multiple sclerosis. Physical Medicine and Rehabilitation Clinics of North America. 2005;16(2):513-55.

35. Rahnama N, Namazi Zadeh M, Etemadifar M, Bambaeichi E, Arbabzadeh S, Nazarian AB. Effects of Yoga Trainings on Selected Physical Fitness Factors in MS Patients. Olympic. 2011;19(3):95-106 [Article in Farsi].

36. Stuifbergen AK, Blozis SA, Harrison TC, Becker HA. Exercise, Functional Limitations, and Quality of Life: A Longitudinal Study of Persons With Multiple Sclerosis. Archives of physical medicine and rehabilitation. 2006;87(7):935-43.

37. Heesen C, Romberg A, Gold S, Schulz KH. Physical exercise in multiple sclerosis: supportive care or a putative disease-modifying treatment. Expert review of neurotherapeutics. 2006;6(3):347-55. 
تازههاى علوم كاربردى ورزش

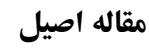

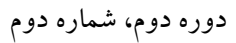

تاريخ دريافت:

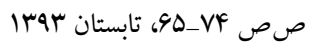

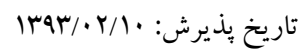

\section{اثر 1 هفته تمرين ايروبيك بر اضطر اب بدنى - اجتماعى زنان

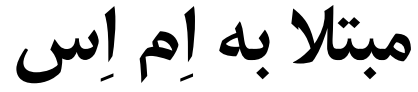

\section{'فروغ رحمتى * 'آحسان زارعيان}

ا. كارشناسى ارشد رفتارحر كتى، دانشكده تربيتبدنى و علوم ورزشى، دانشكاه علامه طباطبايى، تهران، ايران.

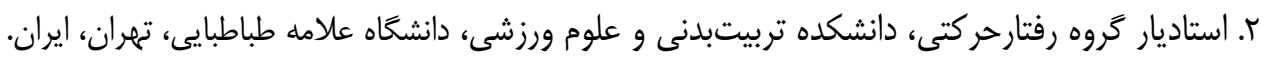

جكيده

امروزه بيمارىهايى كه تحت عنوان بيمارىهاى خاص شناخته مى شوند، كريبان كير جامعلاى هستند كه در آن زندگى مى كنيم. امروزه تحقيقات

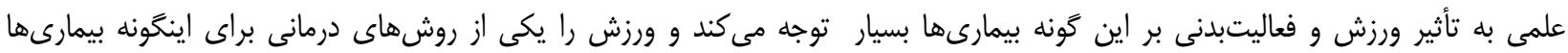

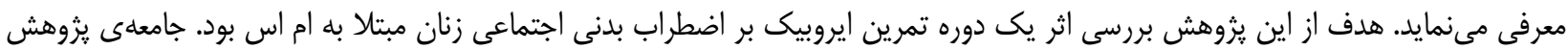

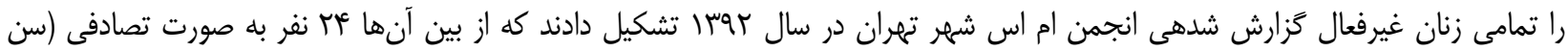

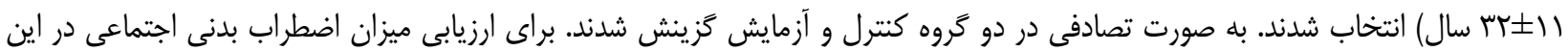

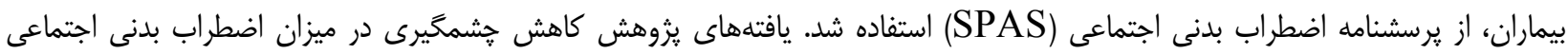

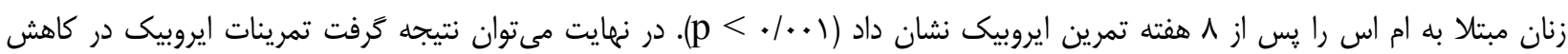

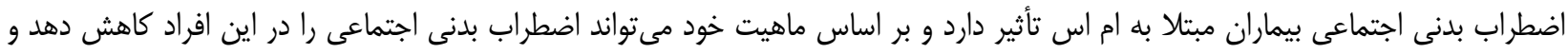
باعث ارتقاء سلامتى و مشاركت در فعاليتهاى ورزشى شود. وازَّان كليدى: ايروبيك، اضطراب بدنى اجتماعى، ام اس. 
